\title{
Technopreneurship Skills of Indonesian Entrepreneurs
}

\author{
C T Adhikara ${ }^{1}$, Lasmy ${ }^{1}$, Sasmoko $^{2,3}$, Y Indrianti ${ }^{3}$ \\ ${ }^{1}$ Management Department, Universitas Bina Nusantara, Jakarta, Indonesia \\ ${ }^{2}$ Professor, Faculty of Humanity, Universitas Bina Nusantara, Jakarta, Indonesia \\ ${ }^{3}$ Research Interest Group in Educational Technology, Universitas Bina Nusantara, Jakarta, \\ Indonesia \\ ${ }^{1}$ ctadhikara@binus.ac.id
}

\begin{abstract}
As the world becomes borderless, geopolitics changes, and people increase singly care about the environment, the way to conduct business is changing. To be able to survive, a company must be adaptive and innovative. This situation encourages two important things that happen in Indonesia : the increasing of entrepreneurship awareness and the rapid growth of digital economy. Combine with the implementation of ASEAN Economic Community (AEC) and 'green'er technology, all these causes support the growth of technopreneur in indonesia. This study aims to examine technopreneurship skills of entrepreneurs in Indonesia. Its design takes in consideration of three variables ; Creative and innovative, Persistence when experiencing difficulties, and Social networking. The results of the analysis prove that the ability to build Social Networking (X3) is the most dominant dimension to determine the realization of Technopreneurship Skill of Indonesian entrepreneurs (Y). If the ability to build Social Networking of Indonesian entrepreneurs is enhanced through 1 (one) priority program, then Technopreneurship Skill of Indonesian entrepreneur (Y) will increase by 24,434 times from current condition.
\end{abstract}

Keywords: Technopreneurship, Entrepreneurs, Social Networking

\section{INTRODUCTION}

The recognition of entrepreneurship as a solution to a promising future has made the Government of Indonesia seriously improve education and entrepreneurship development through two ministries ; Ministry for Cooperatives Small and Medium Enterprises and Ministry of Manpower and Transmigration. Based on data from the Central Bureau of Statistics (BPS) 2016, with a population of 252 million, the number of settled-non-agricultural entrepreneurs reached 7.8 million people or 3.1 percent. The level of entrepreneurship Indonesia has exceeded 2 percent of the population, as a minimum prosperity requirement of a society. The 3.1 ratio of entrepreneurs percent is still lower than other countries such as Malaysia 5 percent, China 10 percent, Singapore 7 percent, Japan 11 percent and the US 12 percent.

To be a successful entrepreneur must be innovative - applying advanced technique to production. There is a strong connection between technological development and entrepreneurship. Technology makes entrepreneurship dynamic; it encourages diversification and economies of scale [1] Along with entrepreneurship awareness in Indonesia, there are 
trend of Technopreneur in rising. New words are enriching the vocabulary as even the name of some journals displays $($ Technovation $=$ Technology and Innovation; Techno entrepreneurship $=$ Technology and Entrepreneurship). Consequently, considering all the above, it makes more sense to call Technopreneurship the common zone of inter-disciplinarity between all three area of interest: technology, entrepreneurship, and innovation ; not only the technology entrepreneurship zone [2].

The Indonesia government itself in 2014 has a declaration program of 1000 technopreneur. It is a continuous program from several year ago. From Kompas Newspaper in June 17, 2011 quoted (1) Only 0.24 percent of the 53 million entrepreneurs in Indonesia are classified as technopreneurs running a technology-based business; This is one of the reasons why the industry and research institutions in Indonesia are not developing. (2) Agency for Assessment and Applied Technology (BPPT) implement 7 districts / cities for Technopreneurship program : Cimahi for creative animation and film industry, Surabaya, Tegal and Banyumas in silent engine development, Pekalongan for multi-business especially batik, Surakarta in natural dyes and seaweed processing equipment, and South Sumatera related rubber-based products [2].

\section{LITERATURE REVIEW}

Entrepreneurs achieve success by creating value in the marketplace when they combine resources in new and different ways to gain a competitive edge over rivals. Entrepreneurs can create value in a number of ways inventing new products and services, developing new technology, discovering new knowledge, improving existing products or services, finding different ways of providing more goods and services with fewer resources, and many others [3].

Research from Milton-Smith in several countries found that Asian SME owner-managers demonstrate a serious lack of Strategic Management skills, perspective and commitment. They operate in an environment which discourages creativity, risk taking and experiment - and especially in technology - related industries which require long-term vision, heavy up-front investment and exceptional tolerance of failure [4]. The case of Singapore, Government has invested heavily in trying to cultivate technopreneurs. However, the research indicates that, in the current environment, very few Singaporean entrepreneurs are likely to develop long term visions, design original business models or conduct radical experiments in any area in which the government plays an active role. In the case of Taiwan, government has concentrated upon simulating 'the Silicon Valley Effect' by creating the sort of environment where innovative people and innovative companies might flourish. This approach is in contrast to the mechanistic programs initiated by governments elsewhere in Asia, where there has been little attempt to link innovation and technopreneurship strategies with the provision of supportive cultural contexts.

In Malaysia, Government play an important role in the development of technopreneurships. Under the Eighth Malaysia Plan, the government has decided to boost the growth of SMEs in information and communication technology industry through its various assistance programs. Besides, the findings demonstrated that the government has placed equal opportunities for technology-based entrepreneurs and ICT SMEs to participate in the local ICT market as the government realized the importance of SMEs in growing the nation. In addition to that, it is evidenced by the commitment put by the government to support entrepreneurial activity around the country by having various "farming" programs such as incubation programs and communication programs for technopreneurs to grow. MARA Strategic Plan (2011-2015) has 
set a target to groom 40,000 new entrepreneurs in 2015. Government policies that form the basis of the implementation of the MARA Technopreneurship Program are i) National Industrial Master Plan ii) National Science and Technology Policy, iii) Bumiputera Commercial and Industrial Community Basics, iv) National Key Economic Areas and v) Economic Transformation Plan [5], [6].

Indonesia has its own characteristic about the implementation of Digital technologies and technopreneur. Aside from the creative destruction and disruption to traditional business models, digital technology also increase issue called 'digital resource nationalism'. Central to future policy settings for the digital economy in Indonesia will be broader debates about the effectiveness of globalisation and free-trade, and the role of nationalistic economy policymaking. Few example from Juriens [7], stated that (1) Indonesian technopreneurs still have to learn a lot compared to Silicon Valley's. (2) the Indonesian government frequently claims that large foreign corporations are deliberately and regularly underpaying taxes. (3) the entry of foreign tech company (such as Grab) has led to calls to ensure the success of locally grown companies (such as Go-Jek) even though Adhikara found that Go-Jek has stronger brand than Grab[8].

This research identified personal entrepreneurial competencies (PECs) which appear to characterize the Behavior of successful entrepreneurs and grouped into 3 dimension: 1) Creative and Innovative, 2) Persistence when experiencing difficulties, 3) Social Networking.

\section{METHODS}

Self-administered questionnaire were used in this study to obtain data from entrepreneur in Indonesia conducted during the period March to April 2018. They are 545 SMEs in many products and services. Since the respondents are usually busy, the questionnaire were designed in a manner that enabled entrepreneurs to complete it with ease in a short period. A five point Likert scale was used where the entrepreneurs/SMEs owners were asked to state the extent to which they agreed or disagreed with the statements in the questionnaire. Data analysis was carried out using SPSS (version 21).

\section{RESULTS AND DISCUSSION}

\subsection{Calibration of Technopreneurship Skill of Indonesian Entrepreneurs (instruments Y)}

Calibration of Technopreneurship Skill of Indonesian Entrepreneurs instruments (Y) was done with the content validity of the instrument by expert judgment. The expert is entrepreneurs and academics. The results of content validity produced 3 dimensions, 8 indicators, and 10 items. Construct validity is done through Orthogonal Iteration. Sample of research instrument amounted to 30 people, with $\mathrm{R}$ (correlation)-criterion 0,361 at $5 \%$ significance level. The result of construct validity of 10 items planned, after the Orthogonal Iteration 1 (one) time turns out all valid items as valid instrument description. Then, the calculation of instrument reliability index of Technopreneurship Skill of Entrepreneur Indonesia (Y) with Cronbach Alpha formula is 0,770 which means reliable data in this research. 


\subsection{Normality Data Test Variables and Dimensions of Technopreneurship Skill of Entrepreneur Indonesia (Y)}

The data normality test is performed to test the distribution of exogenous variables data including Creative and Innovative (X1), Persistence when experiencing difficulties (X2), Social Networking (X3), and Technopreneurship Skill of Indonesian Entrepreneur (Y) as endogenous variable. Normality test is done using Proportion Estimation through Blom Formula with Q-Q Plot approach. The Q-Q Approach Plot was taken because the sample size was> 200 people.

Based on the calculation of Normal Plot Q-Q resulted in all endogenous and exogenous normal distributed variables, and the data distribution has no outlier. Similarly, when viewed from the Detrended Normal Q-Q Plot it, the data distribution does not depict a sinus or cosine curve. So it can be concluded that the distribution of all data variables are normally distributed. Graphically the results can be seen below.
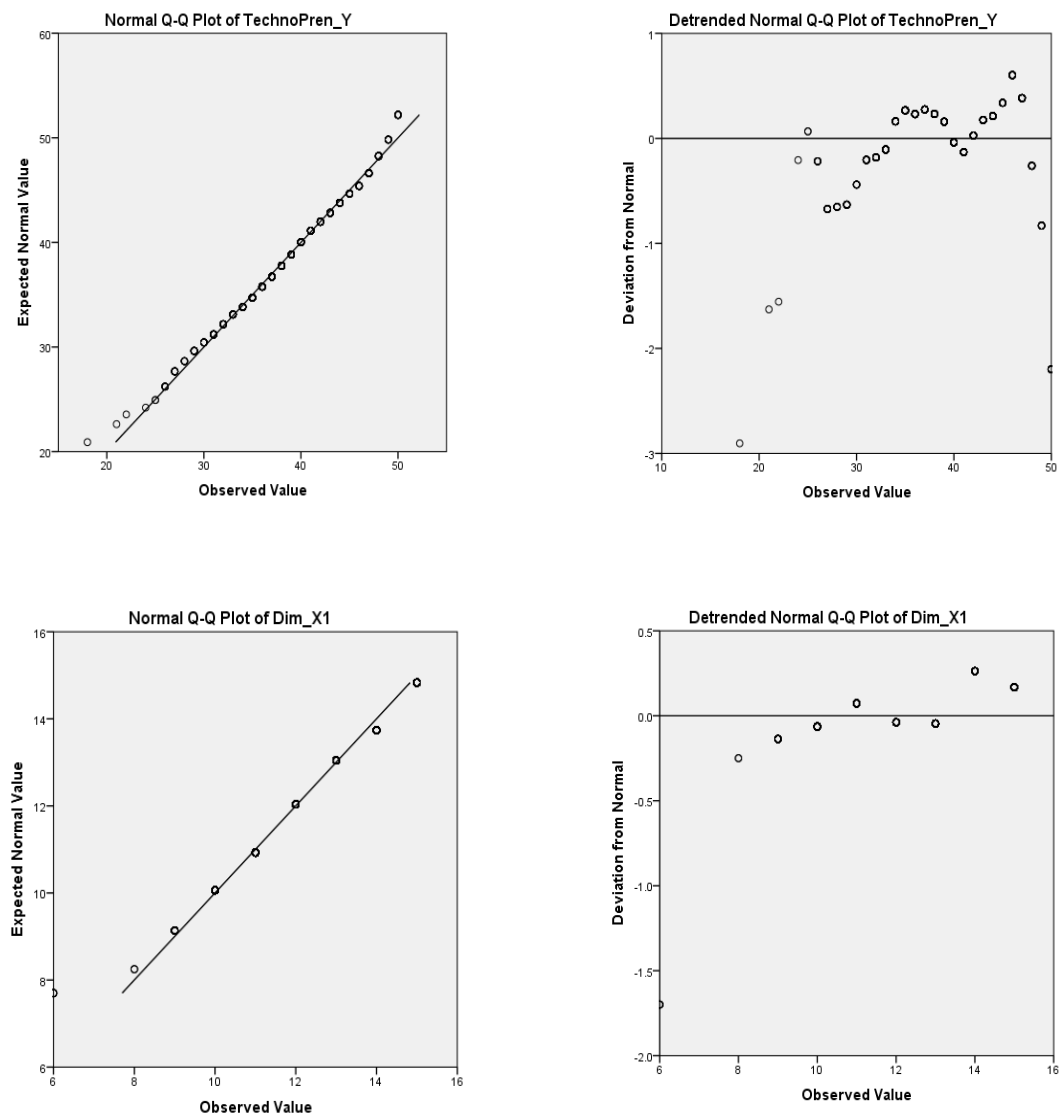

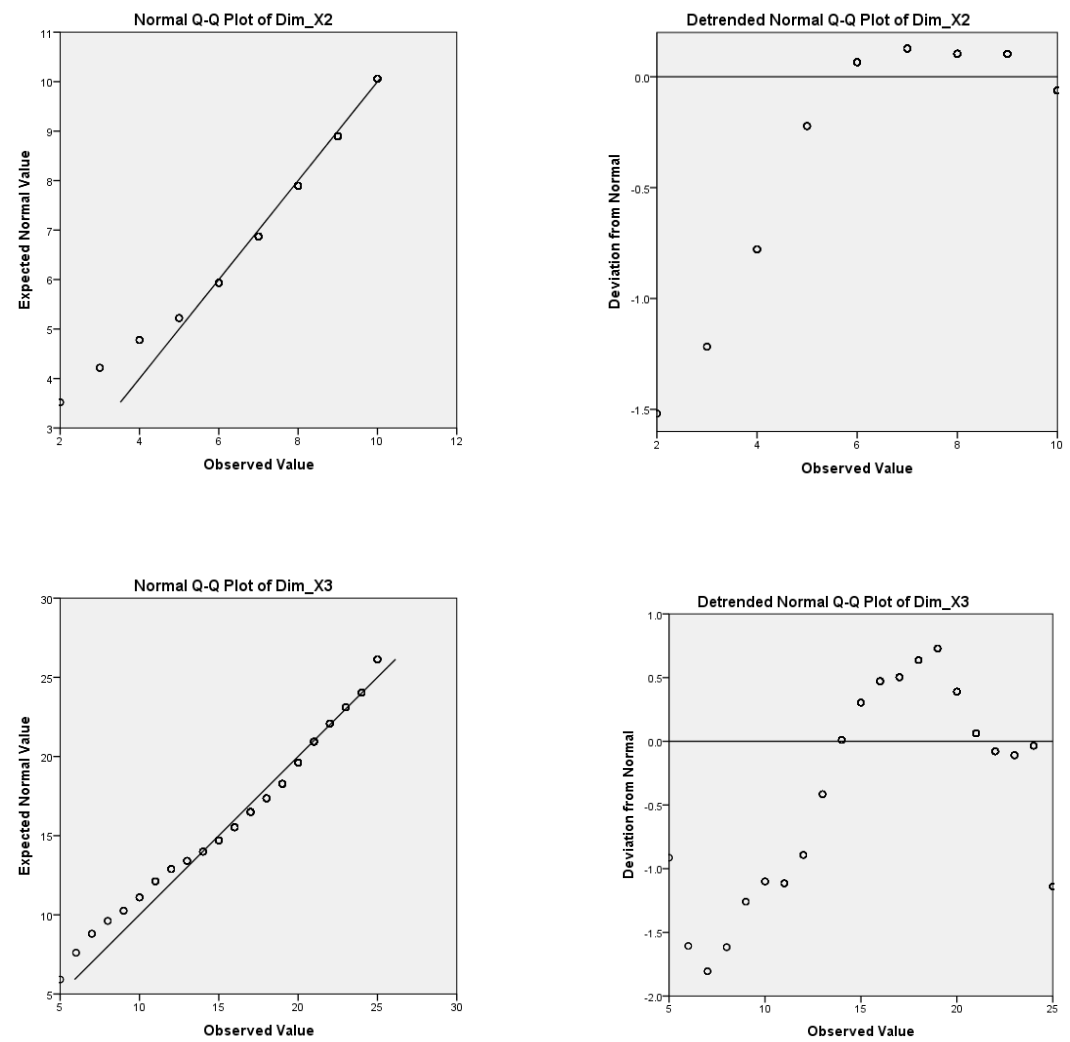

Figure 1. Normality Data Test

4.3 Linearity Relationship Test between Exogenous Variable and Variable Technopreneurship Skill of Indonesian Entrepreneur (Y) as Endogenous Variable

The results of linearity test between exogenous variables include Creative and Innovative (Dim_X1) or $\left(\mathrm{X}_{1}\right)$, Persistence when experiencing difficulties $\left(\operatorname{Dim} \_X 2\right)$ or $\left(\mathrm{X}_{2}\right)$, and Social Networking (Dim_X3) or $\left(\mathrm{X}_{3}\right)$, with endogenous variable Technopreneurship Skill of Indonesian entrepreneur $(\mathrm{Y})$ can be seen in following table.

Table 1. Relationship Test

\begin{tabular}{|c|c|c|c|c|c|c|}
\hline \multirow[t]{2}{*}{ No } & \multirow[t]{2}{*}{ Linearity $\mathrm{Y}$ from $\mathrm{X}$} & \multicolumn{2}{|c|}{$\begin{array}{l}\text { Deviation from } \\
\text { Linearity }\end{array}$} & \multirow{2}{*}{$\begin{array}{l}\text { F from } 11 \\
\text { Curve's } \\
\text { Estimation }\end{array}$} & \multirow[t]{2}{*}{ Sig } & \multirow[t]{2}{*}{ Remarks } \\
\hline & & $\mathrm{F}$ & Sig. & & & \\
\hline 1. & $\begin{array}{l}\text { Creative and Innovative }\left(\mathrm{X}_{1}\right) \\
\rightarrow \text { Technopreneurship Skill }(\mathrm{Y})\end{array}$ & 1,518 & 0,158 & - & - & Linear \\
\hline 2. & $\begin{array}{l}\text { Persistence when experiencing } \\
\text { difficulties } \\
\rightarrow \text { Technopreneurship Skill (Y) }\end{array}$ & 0,846 & 0,550 & - & - & Linear \\
\hline 3. & $\begin{array}{l}\text { Social Networking }\left(\mathrm{X}_{3}\right) \\
\rightarrow \text { Technopreneurship Skill }(\mathrm{Y})\end{array}$ & 3,797 & 0,000 & 1808,351 & 0,000 & Linear \\
\hline
\end{tabular}


All line relationships between exogenous variables include Creative and Innovative (Dim_X1) or $\left(\mathrm{X}_{1}\right)$, Persistence when experiencing difficulties (Dim_X2)or (X2), and Social Networking (Dim_X3) or (X3), with endogenous variables Techno preneurship Skill of Indonesian entrepreneur (Y) are proved linear.

\subsection{Test of Hypotheses 1: Indonesian Entrepreneurs Sometimes Tends to Have Skill That Reflects Technological-Based Entrepreneur Significantly on $\alpha<0,05$ )}

In proving each variable, the researcher in this case specifies 3 (three) categories which result as the following table. Based on these results, it can be concluded that Indonesian entrepreneurs sometimes tend to have skill significantly at $\alpha<0,05$.

Table 2. Test of Hypotheses 1

\begin{tabular}{|c|c|c|c|c|}
\hline Variable & Categories & $\begin{array}{l}95 \% \\
\text { Interval for } \\
\text { Lower } \\
\text { Bound }\end{array}$ & $\begin{array}{l}\text { Confidence } \\
\text { Mean } \\
\text { Upper } \\
\text { Bound }\end{array}$ & 1. Analysis Results \\
\hline $\begin{array}{l}\text { Technopreneu } \\
\text { rship Skill (Y) }\end{array}$ & $\begin{array}{l}\text { 1. Conservative } \\
\text { Skill } \\
\text { 2. Sometimes }+/- \\
\text { 3. Technopreneur } \\
\text { ship Skill }\end{array}$ & 37,9726 & 38,9412 & $\begin{array}{l}\text { Indonesian entrepreneurs } \\
\text { tend to sometimes have } \\
\text { skills that reflect } \\
\text { technologically-based } \\
\text { entrepreneurs significantly at } \\
\alpha<0.05\end{array}$ \\
\hline $\begin{array}{l}\text { Creative and } \\
\text { Innovative } \\
\left(\mathrm{X}_{1}\right)\end{array}$ & $\begin{array}{l}\text { 1. Not creative } \\
\& \text { not } \\
\text { innovative } \\
\text { 2. Sometimes } \\
\text { 3. Creative \& } \\
\text { Innovative }\end{array}$ & 12,2531 & 12,5505 & $\begin{array}{l}\text { Indonesian entrepreneurs } \\
\text { tend to be creative and } \\
\text { innovative significantly on } \alpha \\
<0,05\end{array}$ \\
\hline $\begin{array}{l}\text { Bertahan } \\
\text { dalam } \\
\text { Kesulitan }\left(\mathrm{X}_{2}\right)\end{array}$ & $\begin{array}{l}\text { 2. Can not stand } \\
\text { it } \\
\text { 3. Sometimes } \\
\text { 4. Hold on }\end{array}$ & 7,6398 & 7,9089 & $\begin{array}{l}\text { Indonesian entrepreneurs } \\
\text { tend to be in a condition of } \\
\text { having the ability to survive } \\
\text { in difficulties significantly at } \\
\alpha<0,05\end{array}$ \\
\hline $\begin{array}{l}\text { Social } \\
\text { Networking } \\
\left(\mathrm{X}_{3}\right)\end{array}$ & $\begin{array}{ll}\text { 1. } & \text { Do not have } \\
\text { networking } \\
\text { 2. } \\
\text { 3. } \\
\text { Having } \\
\text { networking }\end{array}$ & 17,9180 & 18,6435 & $\begin{array}{l}\text { Indonesian Entrepreneurs } \\
\text { tend to occasionally build } \\
\text { social networking } \\
\text { significantly on } \alpha<0.05\end{array}$ \\
\hline
\end{tabular}

4.5 Test of Hypotheses 2: Ability to Build Social Networking $\left(\mathrm{X}_{3}\right)$ is the Most Dominant Significant Dimension Determining the Realization of Technopreneurship Skill of Entrepreneur Indonesia (Y)

In proving hypothesis 3, 2 stages are analyzed: first, self-analysis of variables and Technopreneurship Skill individually on Technopreneurship Skill (Y). And second, the joint 
analysis of the variables and dimensions of Technopreneurship Skill both against Technopreneurship Skill (Y). The analysis is done 2 (two) times in order to see the consistency of the most dominant variable or dimension in realizing Technopreneurship Skill of Indonesian Entrepreneur (Y).

4.6 Firstly, Analysis of the effect exogenous variables partially include Creative and Innovative (X1), Persistence when experiencing difficulties (X2), and Social Networking (X3), with endogenous variables Technopreneurship Skill of Indonesian Entrepreneurs (Y)

Table 3. Result of Effect Calculation Individually exogenous variables include Creative and Innovative (Dim_X1) or (X1), Persistence when experiencing difficulties (X2), and Social Networking (X3), to Technopreneurship Skill of Indonesian entrepreneur (Y) as endogenous variable.

\begin{tabular}{|c|c|c|c|c|c|}
\hline No. & Analysis & Symbol & $\mathrm{X}_{1} \rightarrow \mathrm{Y}$ & $\mathrm{X}_{2} \rightarrow \mathrm{Y}$ & $\mathrm{X}_{3} \rightarrow \mathrm{Y}$ \\
\hline 1. & $\begin{array}{l}\text { Correlation between } \mathrm{X} \text { and } \mathrm{Y} \text { in } \\
\text { sample }\end{array}$ & $r_{y n}$ & 0,572 & 0,603 & 0,877 \\
\hline 2. & Variance determination & $r^{2}$ yn & 0,326 & 0,363 & 0,769 \\
\hline 3. & $\begin{array}{l}\text { The relative contribution of } \mathrm{X} \text { in } \\
\text { forming Y }\end{array}$ & $\mathrm{r}_{\mathrm{yn}}^{2}(\%)$ & 32,6 & 36,3 & 76,9 \\
\hline 4. & $\begin{array}{l}\text { Correlation betwen } \mathrm{X} \text { and } \mathrm{Y} \text { in } \\
\text { population }\end{array}$ & $\mathrm{t}$ & 16,240 & 17,620 & 42,525 \\
\hline 5. & Significance value & Sig. & 0,000 & 0,000 & 0,000 \\
\hline 6. & The effect of $\mathrm{X}$ on $\mathrm{Y}$ in the sample & $\hat{\mathrm{Y}}$ & $1,862 \mathrm{X}_{1}$ & $2,171 X_{2}$ & $1,171 \mathrm{X}_{3}$ \\
\hline 7. & $\begin{array}{l}\text { The effect of } \mathrm{X} \text { on } \mathrm{Y} \text { in the } \\
\text { population }\end{array}$ & $F_{\text {Reg }}$ & 263,730 & 310,475 & 1808.351 \\
\hline 8. & Significance value & Sig & 0,000 & 0,000 & 0,000 \\
\hline 9. & The greatest pure relationship & $\mathrm{r}_{\text {yn.m }}^{2}$ & 0,861 & 0,822 & 0,955 \\
\hline 10. & $\begin{array}{l}\text { A relatively pure donation of } \mathrm{X} \\
\text { with } \mathrm{Y}\end{array}$ & $\begin{array}{c}\mathrm{r}_{\text {yn.m }}^{2} \\
(\%)\end{array}$ & 74,1 & 67,7 & 91,2 \\
\hline
\end{tabular}

Information :

Endogenous Variable:

Y : VariabelTechnopreneurship Skill of Indonesian entrepreneurs

Exogenous Variables:

$\mathrm{X}_{1}$ : Creative and Innovative Dimensions

$\mathrm{X}_{2}$ : Persistence when experiencing difficulties Dimension

$\mathrm{X}_{3} \quad$ : Social Networking Dimensions

The results of the analysis of individual influences of exogenous variables include Creative and Innovative (X1), Persistence when experiencing difficulties (X2), and Social Networking (X3), to Technopreneurship Skill of Indonesian entrepreneur (Y) can be seen in Table 3. It can be explained that the ability to build Social Networking (Dim_X3) or(X3) is the most dominant dimension determining the realization of Technopreneurship Skill of Indonesian entrepreneur (Y) after being influenced by Creative and Innovative Dimension (Dim_X1) or (X1). The ability to contribute in forming Technopreneurship Skill of Indonesian 
entrepreneurs $(\mathrm{Y})$ is $91.2 \%$. The conclusion of partial effect analysis can be shown with the following figure.

Endogenous Variable:



Y : VariabelTechnopreneurship Skill of Indonesian entrepreneurs

Exogenous Variables:

$\mathrm{X}_{1}$ : Creative and Innovative Dimensions

$\mathrm{X}_{2}$ : Persistence when experiencing difficulties Dimension

$\mathrm{X}_{3}$ : Social Networking Dimensions

Figure 2. The Results of the Analysis of Individual Influences of Exogenous Variables.

4.7 Second, Analysis the effect of exogenous variables Partially include Creative and Innovative (X1), Persistence when experiencing difficulties (X2), and Social Networking (X3), with endogenous variable Technopreneurship Skill of Indonesian entrepreneur (Y)

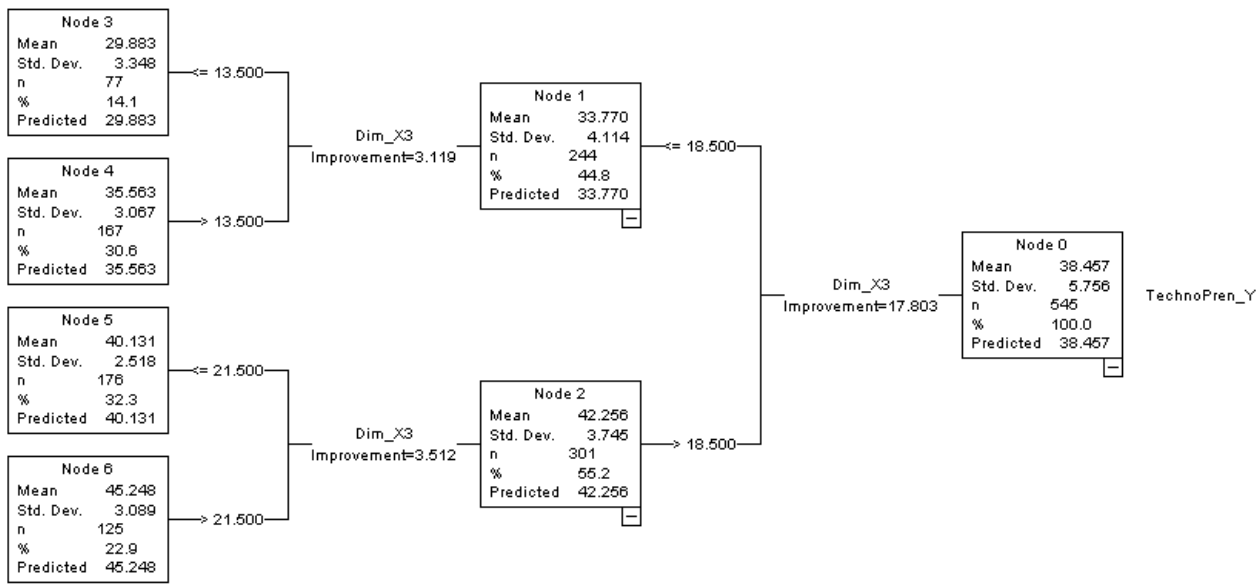

Figure 3. The Results of The Analysis of All Variables

The second hypothesis test is done by Binary Segmentation analysis approach called Classification and Regression Trees. In this analysis, the researchers set the Prunning of Depth 
by 2 , Parent 2 , and Child by 1 , with significance level $\alpha<0,05$. The results of the analysis prove that the ability to build Social Networking (Dim_X3) or (X3) is the most dominant dimension to determine the realization of Technopreneurship Skill of Indonesian entrepreneurs (Y). If the ability to build Social Networking of Indonesian entrepreneurs is enhanced through 1 (one) priority program, then Technopreneurship Skill of Indonesian entrepreneur (Y) will increase by 24,434 times from current condition. In summary can be seen in the figure below.

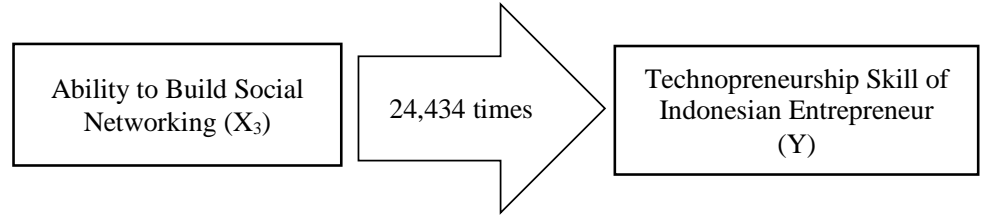

Figure 4. Indicators in Having Motivation in Achieving Goals (X7) that determines the dimension of Self Confidence of Indonesian entrepreneurs (X1) Impacting on its influence on Positive Organizational Behavior of Indonesian entrepreneurs (Y).

Based on the results of the research above, the conclutionfrom the second hypothesis, The Ability to Build Social Networking (X3) is the most dominant dimension determining the formation of Technopreneurship Skill of Indonesian entrepreneur (Y) is proven in this research.

\section{CONCLUSION}

From data analysis conducted in quantitative method, it can be concluded that :

1. Indonesian entrepreneurs tend to sometimes have skills that reflect technologically-based entrepreneurs significantly at $\alpha<0.05$

2. Indonesian entrepreneurs tend to be creative and innovative significantly on $\alpha$ $<0,05$

3. Indonesian entrepreneurs tend to be in a condition of having the ability to survive in difficulties significantly at $\alpha<0,05$

4. Indonesian Entrepreneurs tend to occasionally build social networking significantly on $\alpha<0.05$

5. The Ability to Build Social Networking (X3) is the most dominant dimension determining the formation of Technopreneurship Skill of Indonesian entrepreneur (Y)

The results of the analysis prove that the ability to build Social Networking is the most dominant dimension to determine the realization of Technopreneurship Skill of Indonesian entrepreneurs. If the ability to build Social Networking of Indonesian entrepreneurs is enhanced through 1 (one) priority program, then Technopreneurship Skill of Indonesian entrepreneur will increase by 24,434 times from current condition. 


\section{REFERENCES}

[1] N. Okorie, "Technopreneurship: An Urgent Need in the Material World for Sustainability in Nigeria," Eur. Sci. J., vol. 10, no. 30, 2014.

[2] C. Scarlat, "Technopreneurship - An Emerging Concept," FAIMA Bus. Manag. J., vol. 2, no. 3, pp. 5-13, 2014.

[3] A. Harsono, "Building Technopreneurship for Next Generation : How the Benefits of Techno - Entrepreneurship Education Affect Career Intentions of College Students,” J. Ilm. Sisfotenika, vol. 3, no. 1, pp. 31-40, 2013.

[4] J. M. Smith, "Developing Technopreneurs In Asia," Perth, 2003:1, 2003.

[5] S. Suradi, "Increasing Technopreneurs for A Developing A Nation: The Majlis Amanah Rakyat (Mara) Experience,” J. Tech. Educ. Train., vol. 9, no. 1, 2017.

[6] M. A. Jusoh and H. Halim, "Role of Technopreneurs in Malaysian Economic," J. Glob. Bus. Manag., vol. 2, no. 2, 2006.

[7] E. Jurriëns and R. Tapsell, "Challenges and opportunities of the digital 'revolution' in Indonesia," in Digital Indonesia, E. Jurriens, Ed. Singapore: ISEAS-Yusof Ishak Institute Singapore, 2017, pp. 1-18.

[8] C. T. Adhikara and K. C. B. Wicaksono, "Brand image analysis of online Ojek apps service: (Case study of Go-Jek \& GrabBike motorcycle taxi in Jakarta)," in 2017 International Conference on Information Management and Technology (ICIMTech), 2017, pp. 288-293. 